\title{
Sport in the Piarist Stanisław Konarski Gymnasium in Rakowice in 1909-39
}

\begin{abstract}
The article shows the role of physical education in the Piarist priests' gymnasium in Rakowice near Kraków in 1909-39, a period when sport entered the school curriculum on a permanent basis. In the Interwar period, the order was able to open more schools in Lida, Szczuczyn Nowogródzki, and Lubieszów. The school in Rakowice was modern and comfortable and enjoyed a growing reputation among wealthy Polish society. The Rakowice school took great care of the physical development of young people. The article uses source materials describing the physical education of this institution. In this school, sport was considered to be an important educational factor, and the monks also saw it as an element of improving health, hygiene and finally, civic education. Polish society and the Polish state needed educated and healthy youth. However, it should be noted that this school was an elite, paid school, attended by children from wealthy families who were more aware of the importance of sport. This also contributed to the fact that the gymnasium had great facilities for practising sports, which many excellent secondary schools of that period could envy.
\end{abstract}

Keywords: Piarists, sports, gymnastics, Rakowice

\section{Introduction}

The Piarist Order played an important role in the history of Polish education. In the conducted research, the importance of their achievements in the field of didactic and educational work with young people was emphasised. Equally important was their involvement in the popularisation of exercises, physical games and sport among their charges. Historical events and economic factors had an impact on the momentum of the activities, and the undoubtedly committed attitude of the founders of the gymnasium and its teachers contributed to its successes.

After the post-insurrection repressions, the Piarists attempted to return to pedagogical activity. For political reasons, this was only possible in Krakow. The lack of adequate resources did not allow for the opening of a secondary school, which was an important 
objective for them. According to preserved documents, such attempts were made in the 1907/08 school year. At the time, the Piarists opened a private lower gymnasium for boys aged 10-15. For some time, it was located in Ślemień (1907-1908), then the students were moved to Krakow. The actual beginning of the reconstruction of Piarist secondary schools was the creation of a real gymnasium by Father Jan Borrell ${ }^{1}$. The school was established in the 1909/10 school year in the building of the Piarist college on Pijarska Street. On 23 September 1909, an official permit was obtained from the Galician National School Council to run such a school ${ }^{2}$. The rescript from 25 July 1910 allowed for the use of the name "Prince Stanisław Konarski Private Real Gymnasium". At the same time, the school obtained state school rights, which were to be renewed annually on the basis of a visit by a delegate of the National School Council ${ }^{3}$. The school had a boarding house, founded in 1873 by Fr. Słotwiński and intended initially for boys attending public secondary schools in Krakow, and from 1909, mainly for students of the Piarist gymnasium.

The facility, as a real gymnasium, was an alternative to the traditional and dominant classical gymnasium. The school began to function in a more modern form after the reform of Minister Gustav Marchet in $1908^{4}$. It was one of the first such institutions in Galicia, taking into account both public and private real gymnasiums ${ }^{5}$. In real gymnasiums, the number of hours of classical languages was reduced (Greek was abolished and the Latin teaching was reduced by on hour in grades 6 and 7) in favour of modern languages, especially French, which was compulsory in grades 4-7. The number of hours of mathematical-natural subjects - geography, nature, chemistry - was also increased, learning hours of drawing were added and diagram geometry was introduced. This responded to real social needs. The school was paid and after moving to Rakowice (now part of Krakow), it had an elite status, so only wealthy families could afford to send their children there. From 1909/10 until 1916, the school was granted the right of annual public access, and was systematically visited by Tomasz Sołtysik ${ }^{6}$, the director of the Gymnasium No. 3 in Krakow, a representative of the National School Council.

In addition to the compulsory subjects, the Piarist Gymnasium provided a wide range of extracurricular activities. Among them, sporting activities occupied an important place.

${ }^{1}$ M. AUSZ, Odbudowa polskiej prowincji pijarów. Działalność wychowawczo-edukacyjna zakonu w latach 1873-1918, Lublin 2013, pp. 178-179.

2 Central Archives of Ukrainian History in Lviv (hereinafter CAHUL), National School Council (hereinafter RSK), fond 178, description 3, case 965, k. 107.

375 lat Gimnazjum i Liceum im. Ks. St. Konarskiego w Krakowie 1909-1985, ed. T. KORZEŃ, Kraków 1985 , p. 30.

${ }^{4}$ M. STINIA, Nauczyciele gimnazjum realnego oo. Pijarów w Rakowicach pod Krakowem, [in:] Szkolnictwo pijarskie $w$ czasach minionych, a współczesne problemy edukacji historycznej, t. II, red. K. WRÓBEL-LIPOWA, M. AUSZ, Krakow-Lublin 2010, p. 92.

${ }^{5}$ S.I. Możdzeń considered the first state real gymnasium to be established in 1910 in Lviv, Krakow and Łańcut, while the first private real gymnasium in Lviv and Zakopane was established in 1911. See below. S.I. MOSDŻEŃ, Reformy szkoty średniej w Galicji w latach 1884-1914, Kielce 1989, p. 98.

${ }^{6}$ CAHUL, RSK, fond 178, description 3, case 965, k. 105 et seq., fond 178, description 3, case 959, k. 154 et seq.; Sprawozdanie Dyrekcji 1912/13 ..., p. 15. 
As the school assured, it worked according to the latest teaching principles and paid a lot of attention to the moral and physical education of young people, even though the building and the vicinity of the College did not offer a wider range of possibilities in this respect ${ }^{7}$.

In 1890, the National School Council issued a regulation obliging secondary school administrators to work aimed at developing physical activity of students ${ }^{8}$. The Piarist School, following the recommendations of the Galician school authorities, took care not only of the mental development, but also of the physical development of the students. The teachers of gymnastics at that time were Włodzimierz Dutkiewicz, Jan Waszkiewicz from "Sokół" and Kazimierz Zajdzikowski, who, apart from lessons during which Swedish-type gymnastics were practised, organised trips every Saturday to nearby towns of Bielany, Bieńczyce, Michałowice, Tyniec, Raciborowice, Węgrzce, Zielonki and Zabierzów9. Compulsory weekly excursions had been organised since $1910^{10}$. In addition, there were one-and-a-half-hour or two-hour walks every day. Swedish gymnastics replaced exercises with "walking sticks" and weights. The change was due to the fact that Swedish-type gymnastics were supposed to have a better effect on "the straightening of the spine and development of the chest"11. The gymnastics lessons lasted 45 minutes and were planned to affect the entire musculoskeletal system. The lesson started with lighter exercises, gradually increased their difficulty, and then again before the end of the lesson they returned to easier exercises. The sequence of exercises was as follows:

1. leg exercises (as initial exercises),

2. spinal muscle training (bent down),

3. exercises of arm and upper torso muscles (exercises of shoulder blades and upper torso),

4. special exercise of the nervous system (equivalent exercise),

5. abdominal muscle training,

6. lateral torso muscle training,

7. training of the back muscles of the torso (exercises 5, 6, 7 as torso exercises),

8. running and jumping,

9. deep breathing exercises ${ }^{12}$.

7 R. WROCZYŃSKI, Dzieje wychowania fizycznego i sportu od końca XVIII wieku do roku 1918, Wrocław 1971, p. 140. The author emphasised that the lack of adequate premises in many schools made it difficult to introduce gymnastics as a compulsory subject.

8 Sprawozdanie c.k. Rady Szkolnej Krajowej o stanie szkót średnich galicyjskich w roku szkolnym 1890/91, Lviv 1891, p. 28; Ibidem., for the 1899/1900 school year, Lwów 1900, p. 17.

${ }^{9}$ CAHUL, RSK, fond 178, description 3, case 965, k. 105 et seq., fond 178, description 3, case 959, k. 154 et seq.; Sprawozdanie I. Dyrekcyi prywatnego gimnazyum realnego im. X. St. Konarskiego w Krakowie. Rok szkolny 1912/13, Kraków 1913, p. 15.

10 Ibidem, p. 39.

11 Ibidem, p. 40.

12 Ibidem. 
The assessment by inspector Tomasz Sołtysik, in the third year of its operations, before the move to Rakowice, also included a reference to the concern for the physical development of students. It is noted that:

The Stanisław Konarski Real Private Gymnasium has three classes and is currently housed in a monastery building, an old one, but in such a condition that it meets the requirements of hygiene and the needs of the school to a sufficient extent. Next year, the institution will move to a new building, built exclusively for this purpose in a large park near the city. In addition to the compulsory subjects, students will also partake in farming, slöyd and various sports classes there.

Although the internal classroom appliance is not sophisticated, it does fulfil its purpose without compromising the normal course of school life.

The collection of scientific resources, although still rather modest, is sufficient for the current number of classes; they will not be lacking for the further classes, as the owners of the school want to keep it up with today's didactics requirements.

The number of students is relatively small - 28 in all three classes - being mostly wealthier boys, who, although they do not recommend themselves for their outstanding abilities, living in the boarding house under the care of priests, successfully develop both intellectually and morally, as well as physically.

The priests pay careful attention to this latter consideration. They try to ensure that their students not only do their homework diligently, but also receive healthy food and regularly partake in gymnastics and walks, combined with games in the open field.

Thanks to constant care, discipline is also completely satisfactory and they behave quite exemplarily at school and outside of school, without, however, getting rid of their age-appropriate liveliness and serenity of mind $[\ldots]^{13}$.

According to the opinion of the school inspector, despite unfavourable premises, the Piarists paid a lot of attention to the physical education of young people.

The relocation of the school to Rakowice at the beginning of 1913/14 created the conditions for more intensive implementation of physical activities. The pedagogical staff together with the students began working in one of the most modern school buildings in Galicia. This scientific and didactic complex housed a school and rich sports and recreation facilities (pitches, courts, swimming pool, bowling alley, shooting range, areas for cyclists and horseback riding) as well as a dormitory. A three-storey Belgian system building (modelled on the Les Roches School) with a double-glazed roof, as well as other buildings serving as facilities for the school and the boarding house, were built on the 18-morgen plot of land. The central hall of the school, measuring $30 \times 12 \mathrm{~m}$, was the most impressive. It should be noted that the school building in question did not refer to a typical Galician horseshoe-shaped gymnasium, which was one of the most popular models - originating from Vienna and with additional Italian tradition ${ }^{14}$. In 1913, the building of the new school received a high mark from the inspector Tomasz Sołtysik. He predicted that the institution

13 Ibidem, fond 178, description 3, case 959, k. 172-174.

${ }^{14}$ See: M. GUTOWSKI, Architektura szkól średnich w Polsce w okresie zaborów, Rozprawy Naukowe, Politechnika Białostocka, no. 5/91, p. 89-127. 
would enjoy popularity, particularly among the wealthier society ${ }^{15}$. It is to be assumed that the Piarists were proud of the new school complex. It was not as monumental as the Jesuit centre in Chyrowo, but thanks to modern and aesthetic architectural solutions, as well as its surroundings, it was a showpiece of the pedagogical activity of the Piarists ${ }^{16}$. As predicted by inspector Sołtysik, mainly boys from well-to-do families were enrolled there.

The buildings and equipment were not the only asset for the school - the surrounding area was also of great value. A value that was noticed was the proximity of Rakowice to the city, the surrounding greenery, the quiet and, most of all, suitable conditions for boys to take part in sports in a large area belonging to the Piarists. On this occasion, among others, the magazine Świat published an article describing the development of education in Galicia, which also mentioned the merits of Piarists for Polish education and described the new headquarters:

Just as in the 18th century, the Piarists are progressive educators. They are going along with the flow of their time. They know that "sport is to be on an equal footing with Latin", they know how to create an atmosphere of mutual trust towards young people, the atmosphere of a "school family", they put special emphasis on character, on the development of independence, on the essential and complete preparation of the child for the future life, they remember that modern school should empower and arm students for this life.

The new, exemplary Polish school is to be welcomed with joy. Beautiful, full of light and air, shaded with the greenery of the old park, the school building in Rakowice will accommodate one hundred boys - and will raise one hundred future brave citizens of the country... ${ }^{17}$

As the above records show, both the school building and its surroundings, especially the surrounding nature, were conducive to physical activity.

The construction of the Rakowice complex was undoubtedly a great achievement of the Polish province. First of all, it allowed for the expansion of the educational offer - this was the main goal of the Piarists. Pupils, as well as residents of the boarding house, were provided with appropriate fun, slöyd, bookbinding, horticulture, photography and various sports were introduced ${ }^{18}$. It should be added that the school had two pitches (four in the interwar period), two ball courts, a gym, a swimming pool and a vast park. Many sports were therefore practised, including horse riding, biking, hockey, rowing, shooting and tennis, with scouting also enjoying significant interest of the young people. The movement has played an important role in promoting sport among schoolchildren. Since 1910, scouting functioned at the gymnasium, in 1913 the official name of the troop was the 1st Stefan

15 M. STINIA, Nauczyciele gimnazjum realnego oo. Pijarów..., p. 92.

${ }^{16}$ M. STINIA, Wychowanie estetyczne w prywatnych galicyjskich szkołach średnich, [in:] Edukacja. Kultura. Społeczeństwo. Kultura 2010, ed. B. TECHMAŃSKA and M. ZAWADKA, Opole-Wrocław-Lubin 2011, p. 26.

17 Świat, 9.08.1913, p. 12.

18 Archive of the Polish Province of the Piarist Order (hereinafter referred to as APPZP), Collegium Cracoviensis (hereinafter referred to as Coll. Crac.), file 197, Special prints 1887-1930, Zaktad naukowo-wychowawczy xx. Pijarów w Krakowie, advertising print from 1912, passim. 
Czarniecki Rakowice Scouting Troop ${ }^{19}$. The scouts also organised additional excursions, e.g. in January 1910, they made a five-day hike, the route of which led from Ślemień pod Babią Góra through the Beskid to the springs of the Vistula, and then through Żywiec, Andrychów, and Wadowice to Krakow. From 25 to 28 May 1912, the scouts of the Piarist team again wandered around Beskid Żywiecki ${ }^{20}$.

The positive opinion of school inspector Sołtysik concerned the curriculum and the work of the teaching staff concerned the didactics conducted, but it also emphasised the commitment and tactful handling of the students ${ }^{21}$. Teachers were objective in their requirements and properly selected the degree of difficulty. The inspection also shows that priests caring for the youths ensured that they had enough exercise through gymnastics, walking and gardening. In addition, the pupils dealt with animals on the school farm, and manual work carried out using the new Swedish slöyd method was a new pedagogical novelty ${ }^{22}$. This was an element of the so-called polytechnicisation of teaching, which proves that the curriculum applied the most modern principles of didactics and methodology.

As the Piarists wrote, the goal of the school, as well as of the boarding house, located in the countryside away from the city with fresh air, in a place surrounded by a beautiful garden, is to "make a man of the child"23. To achieve this, practical and rational methods of upbringing were to be used, involving the use of persuasion as the main educational method, the introduction of family life into the school, with a sincere and friendly relationship between teachers and students. As has already been mentioned, the Piarists not only took care of good housing conditions and careful upbringing. The documentation of the school's work emphasised this fact: "They devote their free time to physical exercises, manual work, music, fun, trips, etc. Always under professional management" ${ }^{\prime 24}$.

Physical education and various sports were treated on an equal footing with compulsory Latin and mathematics. Handicraft work was to provide students and boarders "with a wide range of uses in addition to pleasure" 25 . As the Piarists themselves wrote, they applied parallelism $n$ the upbringing, which "as a feature of modern upbringing requires balanced development of the spirit and body, strives to harmonise all tendencies and various energies in the child"26.

\footnotetext{
19 Sprawozdanie Dyrekcji 1912/13..., p. 40; B. LEONHARDT, Kalendarium z dziejów harcerstwa krakowskiego, Kraków 2001, p. 22.

20 Sprawozdanie Dyrekcji 1912/13..., p. 40-41.

${ }^{21}$ CAHUL, RSK, fond 178, description 3, case 962, pp. 114-115.

${ }^{22}$ Ibidem, fond 178, description 3, case 959, k. 172.

23 Ibidem, p. 54.

24 Ibidem, p. 53-54.

25 APPZP, Coll. Crac., file 197, Special occasion prints 1887-1930, Zakład naukowo-wychowawczy XX. Pijarów w Rakowicach. Program, Kraków n.d., pp. 3-4.

${ }^{26}$ Ibidem, p. 4.
} 
Apart from their involvement in the development of the students' motor activities, care for their participation in various sports, their health was to be ensured by hot and cold baths, showers, manual work, horticulture, animal husbandry, carpentry, locksmithing and bookbinding. An important element were trips to manors and factories, during which students were to collect minerals, plants, animals, and also "become acquainted with land measurement, drawing up plans, etc.”, i.e. learn the basics of the surveyor's work - a skill especially useful in managing a manor farm ${ }^{27}$. The knowledge and experience gained during the expeditions were perfectly combined with the physical activity much needed by young people. The guideline for working in the school was the following sequence: "Man is a small world in which neatness, order, harmony of all mental and physical powers must reign. Neglecting or misdirecting the development of one of these authorities can be very damaging to people, so educating the spirit cannot neglect the body, developing the mind cannot neglect the shaping of the will and improving the heart!" 28 The above examples of the organisation of the teaching and educational work of the school show the desire for harmonious development of the spirit, body and mind of the students of the Piarist school.

However, the development of the facility was interrupted by the outbreak of World War I. At that time, the gymnasium and boarding house buildings were seized by the army and used as a hospital. The school and the boarding house restarted operations in Rakowice on 1 September 1919. Thanks to the efforts of Provincial Father Jan Borell, the buildings that were occupied by the Polish army after the Austrians were restored.

In the interwar period, a lot of importance was also attached to sports exercises in the Rakowice gymnasium ${ }^{29}$. The state authorities supported the development of physical education because they saw many benefits in it, from politics and propaganda to improving the health of the young generation. Sport had become an important element not only in physical education but also in civic education ${ }^{30}$. In addition to the obligatory two hours of gymnastics lessons per week, the students had additional daily gymnastics and leisure activities in the open air. Guidelines for physical education were included in the following areas:

1. health needs and the development of hygiene habits;

2. cultivating social feelings and developing state-citizenship;

3. the development of positive character attributes.

It should be noted that physical development was to harmonise with moral, patriotic, as well as intellectual development. The Rakowice Gymnasium was essentially a closed facility, with most students living in the boarding house/dormitory, so except for holidays

${ }^{27}$ Ibidem.

${ }^{28}$ Ibidem, pp. 5-6.

29 After the Jędrzejewicz reform, a secondary school was also opened in Rakowice.

${ }^{30}$ O. MOSKA, Moda na sport w II Rzeczpospolitej czynnikiem scalajacym społeczeństwo, [in:] Moda na sport, ed. W. MOSKA, M. BRODNICKI, Z. TYLEWSKA-OSTROWSKA, Gdańsk 2013, p. 77ff. See R. GAWKOWSKI, Sport w II Rzeczpospolitej, Warsaw 2012 for more on the importance of sports in the interwar period in Poland. 
and summer vacations, they remained permanently on the school premises and had a constant rhythm of the day, during which a morning ten-minute gymnastics was also scheduled every day ${ }^{31}$.

Gymnastic exercises in 1918-1939, just like during World War I, were also carried out in the Linga system, i.e. in the "Swedish system" 32 . The programme of sports activities was arranged according to the age of the students, during bad weather the activities were held indoors, and during good weather on school pitches. The most popular summer sports in the Piarist Gymnasium were tennis, volleyball, athletics, swimming, cycling, horseback riding and the "palant" ball game, which is forgotten today. In winter, skating, hockey, tobogganing and skiing were practised ${ }^{33}$. The report of the gymnasium administration reads:

All students in all classes must spend three hours outdoors every day (excursions, games and physical activities) on all good weather days (including winter). On hot spring and summer days they walk barefoot, sunbathe and swim in the river, use the lightest canvas clothing, walk all year round without headgear, except on hot days. Swimming in winter is provided by the pools in the basement of the building ${ }^{34}$.

The report for the 1930/31 school year, on the other hand, reads:

Throughout the year, free periods and special morning hours of physical exercise were used for physical games and activities, as well as time spent on afternoon recreation.

The total time spent outdoors, in unrestrictive light clothing, on hot days without shirts, was up to 4 hours a day in each class ${ }^{35}$. The youths were hardy, strong, healthy, resistant to colds. The infirmary was usually empty ${ }^{36}$.

As we can see, the time spent outdoors was increased. Additionally, so-called "sport Wednesdays" were organised, with gymnastic exercises and sports competitions held after classes $^{37}$. There was a "Młodzi" sports club with the following sections: tennis, athletics, palant, basketball, volleyball, football, rowing, hockey, swimming, tobogganing, skiing, shooting, fencing ${ }^{38}$. The interest in sport was high among the students, as evidenced by the number of registered students in the sports club. In the 1933/34school year, 145 out

\footnotetext{
${ }^{31}$ Sprawozdanie dyrektora gimnazjum prywatnego im. St. Konarskiego O.O. Pijarów w Rakowicach pod Krakowem za rok szk. 1933/34, Kraków 1934, p. 34, 35.

32 W. SIKORSKI, System Linga w zarysie, Lwów 1912, pp. 4-5.

${ }_{33}$ Sprawozdanie zakładu wychowawczo-naukowego im. Ks. St. Konarskiego O.O. Pijarów w Rakowicach pod Krakowem za rok szkolny 1930/31, Kraków 1931, p. 31, 11.

${ }^{34}$ Sprawozdanie dyrekcji pryw. Gimnazjum imienia St. Konarskiego S.P. OO. Pijarów w Rakowicach pod Krakowem z petnemi prawami szkół państwowych. Sprawozdanie za rok szk. 1924/25, Kraków 1925, p. 25.

35 In 1928, the Ministry of Education specified in an ordinance the type of sports costume in detail, exercises without shirts were allowed only in places protected from observation by outsiders. The gymnasium in Rakowice fulfilled this requirement, which is why boys could exercise without shirts on hot days.

36 Sprawozdanie zaktadu... 1930/31, p. 11.

37 Prospekt zakładu naukowo-wychowawczego księży pijarów Rakowcach pod Krakowem. Sprawozdanie za rok szk. 1923-24. Program i warunki przyjęcia, Kraków 1924, p. 27.

${ }^{38}$ Sprawozdanie zakładu... 1930, p. 31, 11-12; Sprawozdanie Dyrekcji... 1933, p. 34, 51-53.
} 
of a total of 195 belonged to the club, and in 1937/38, 102 out of 210 students. The club was supported by the school's funds and members' contributions -10 groszy a month. In 1937/38, the following sections operated: athletics, sports games, tennis, ping-pong, hockey, swimming, cycling, handball and football ${ }^{39}$. It should be recalled that in accordance with the ministerial decree of 1927 , football could be played by schoolchildren from the age of 16 on the grounds that this sport may have a negative impact on children's development due to "excessive effort of nerves and muscles at too young an age". Basketball and volleyball were considered as recommended team sports before the age of 16. Sleigh rides, which at that time were considered sport activities, organised in Bielany, Mogiła, Wola Justowska, Panieńskie Skały, Ojców and other places ${ }^{40}$, were also popular among the youth in winter. The task of all sections was to conduct regular trainings, organise school matches and games and participate in intermural sports competitions. Every year, many members of the sports club competed for the National Sports Badge, e.g. in 1931/32, 75 boys competed for it, and 53 boys won it. ${ }^{41}$

As the pupils themselves wrote:

There is no shortage of athletes in our boarding house at all. There are supposedly too many of them. Consider, for example, those who are passionate about tennis. The boarding house courts can accommodate up to eight players, which is already the maximum. Since there are many more tennis players, however, over time a principle has developed: whoever is the first to play on the court, keeps playing. So 'these guys' take the racquet, hide it behind their backs and, keeping a close eye on Father Prefect, they go for dinner. The meal is eaten at a record speed, waiting for an opportunity to run out of the dining room ${ }^{42}$.

An important supplement to physical education were summer and winter camps, during which students developed their sporting passions. In summer, camps were organised in Wysokie near Gdynia, and in winter, in Zakopane and Mników near Krakow. Often, sightseeing tours were combined with sports, e.g. in the 1937/38 school year, a five-day sightseeing trip to Zakopane for grade 4 was combined with a skiing course ${ }^{43}$.

As mentioned earlier, the scout movement played an important role in promoting sport. In the period of the Second Republic of Poland, the development of physical fitness was largely due to military education classes (PW), which from 1937, were compulsory and were held in all classes at the rate of two hours a week. These activities included not only military elements, e.g. drills, firearms training, etc., but also civic education and

39 Zakład wychowawczo-naukowy O.O. Pijarów w Rakowicach pod Krakowem i filia gimnazjum w Krakowie. Sprawozdanie dyrektorów za rok 1937-38, Kraków 1938, p. 38.

40 Sprawozdanie Dyrekcji... 1926/27, p. 24; Sprawozdanie Dyrekcji O.O. Pijarów im. Ks. St. Konarskiego połaczonego z internatem jako zakładu wychowawczo-naukowego w Rakowicach pod Krakowem, Kraków 1932 , p. 8 .

41 Sprawozdanie Dyrekcji... 1931/32, p. 9.

42 Jednodniówka Gimnazjum im. Ks. Stanisława Konarskiego w Rakowcach wydana ku uczczeniu imienin ks. Rektora St. Paprockiego, 8 V 1937 Rakowice-Kraków, p. 11-12.

${ }^{43}$ Zakład wychowawczo-naukowy..., p. 24; M. AUSZ, Odbudowa polskiej prowincji pijarów ... 
sports exercises, especially running. Students of the Rakowice school, as part of the PW classes, took part in many sports competitions, not only shooting, winning many trophies. It is worth mentioning that the Piarists built a shooting range, which over time was covered, so that the students could practice shooting even in bad weather. In Rakowice, there was also a Club of the Maritime and Colonial League, within which there was a kayaking and sailing section, and individual students attended courses on seagoing yachts ${ }^{44}$.

In conclusion, the Piarists attached great importance to the physical education of young people and saw it as an element of improving their health, hygiene and, finally, civic education. Like others at that time, they believed that Polish society and the state needed young people not only educated but also healthy. As we can see from the analysis of the sources, the Piarists did not stop with the basic curriculum, but significantly expanded the range of sports activities.

A regular element of the day was the daily morning gymnastics, walks held every day. The model of physical education, which went far beyond the obligatory hours of gymnastics, was co-created by organised trips, games during trips, swimming and activities in numerous sports clubs. Apart from the obligatory classes, daily gymnastic and recreational activities took place outdoors. The exercise programme assumed harmonious development of all parts of the body. Positive relations between teachers and pupils were an important element, encouraging active participation in sport. A friendly atmosphere was conducive to sporting achievements. The students organised themselves in numerous sections and were members of the "Młodzi" sports club. In the 1930s, there were several sections: tennis, athletics, basketball, volleyball, palant, football, rowing, hockey, swimming, tobogganing, skiing, shooting, fencing, ping-pong and handball. Regular trainings and sports competitions were held. In winter, there were also sleigh rides, with trips heading out into the closer and further surroundings. The physical fitness of the youth was enhanced by military training. Drills, firearms training, sports exercises, especially running, were a regular part of the training. It is worth noting that the students took part in courses on sea-going yachts during their activities in the Marine and Colonial League and in the kayaking and sailing section.

The physical activity and sporting achievements of the students were supported by the appropriate facilities of the Rakowice complex. The base consisted of, apart from the buildings, two and, in the Second Republic of Poland, four sports pitches, two ball courts, a gym, a swimming pool and a vast park with greenery. The great location and rich sports and recreation facilities combined with appropriate approach and methodical skills of teachers gave excellent results. According to reports, the boys themselves wanted to participate in the sports. Not without significance was the fact that this elite school was attended by students from wealthy families, more aware of the importance of sport and in good physical condition.

${ }^{44}$ Zakład wychowawczo-naukowy..., p. 28, 35. 


\section{Works cited}

Sources

Archiwum Polskiej Prowincji Zakonu Pijarów, Collegium Cracoviensis, sygn. 197, Druki okolicznościowe 1887-1930.

Centralne Archiwum Historii Ukrainy we Lwowie, Rada Szkolna Krajowa, fond 178, description 3, case 965 .

Jednodniówka Gimnazjum im. Ks. Stanisława Konarskiego w Rakowcach wydana ku uczczeniu imienin ks. Rektora St. Paprockiego, 8 V 1937 Rakowice-Kraków.

Prospekt zakładu naukowo-wychowawczego księży pijarów Rakowcach pod Krakowem. Sprawozdanie za rok szk. 1923-24. Program i warunki przyjęcia, Kraków 1924.

Sprawozdanie c.k. Rady Szkolnej Krajowej o stanie szkót średnich galicyjskich w roku szkolnym 1890/91, Lwów 1891.

Sprawozdanie c.k. Rady Szkolnej Krajowej o stanie szkót średnich galicyjskich w roku szkolnym 1899/1900, Lwów 1900.

Sprawozdanie dyrekcji Gimnazjum imienia St. Konarskiego S.P. O.O. Pijarów w Rakowicach pod Krakowem z petnemi prawami szkół państwowych za rok szk. 1926/27, Kraków 1927.

Sprawozdanie Dyrekcji O.O. Pijarów im. Ks. St. Konarskiego połaczonego z internatem jako zakładu wychowawczo-naukowego w Rakowicach pod Krakowem, Kraków 1932.

Sprawozdanie dyrekcji pryw. Gimnazjum imienia St. Konarskiego S.P. OO. Pijarów w Rakowicach pod Krakowem z petnemi prawami szkót państwowych. Sprawozdanie za rok szk. 1924/25, Kraków 1925.

Sprawozdanie Dyrekcji Pryw. Gimnazjum Imienia St. Konarskiego S.P. OO. Pijarów w Rakowicach pod Krakowem z Petnemi Prawami Szkót Państwowych za Rok Szkolny 1925/26, Kraków 1926.

Sprawozdanie dyrektora gimnazjum prywatnego im. St. Konarskiego O.O. Pijarów w Rakowicach pod Krakowem za rok szk. 1933/34, Kraków 1934.

Sprawozdanie I. Dyrekcyi prywatnego gimnazyum realnego im. X. St. Konarskiego w Krakowie. Rok szkolny 1912/13, Kraków 1913.

Sprawozdanie zakładu wychowawczo-naukowego im. Ks. St. Konarskiego O.O. Pijarów w Rakowicach pod Krakowem za rok szkolny 1930/31, Kraków 1931.

Świat, 9.08.1913.

Zakład wychowawczo-naukowy O.O. Pijarów w Rakowicach pod Krakowem i filia gimnazjum w Krakowie. Sprawozdanie dyrektorów za rok 1937-38, Kraków 1938.

\section{Studies}

75 lat Gimnazjum i Liceum im. Ks. St. Konarskiego w Krakowie 1909-1985, ed. T. KORZEŃ, Kraków 1985.

AUSZ M., Odbudowa polskiej prowincji pijarów. działalność wychowawczo-edukacyjna zakonu w latach 1873-1918, Lublin 2013.

GAWKOWSKI R., Sport w II Rzeczpospolitej, Warsaw 2012.

GUTOWSKI M., Architektura szkół średnich w Polsce w okresie zaborów, Rozprawy Naukowe, Politechnika Białostocka, no. 5/91.

MOSKA O., Moda na sport w II Rzeczpospolitej czynnikiem scalajacym społeczeństwo, [in:] Moda na sport, ed. W. MOSKA, M. BRODNICKI, Z. TYLEWSKA-OSTROWSKA, Gdańsk 2013. 
MOŻDŻEŃ S.I., Reformy szkoty średniej w Galicji w latach 1884-1914, Kielce 1989.

SIKORSKI W., System Linga w zarysie, Lwów 1912.

STINIA M., Nauczyciele gimnazjum realnego oo. Pijarów w Rakowicach pod Krakowem, [in:] Szkolnictwo pijarskie $w$ czasach minionych, a wspótczesne problemy edukacji historycznej, vol. II, ed. K. WRÓBEL-LIPOWA, M. AUSZ, Kraków-Lublin 2010.

STINIA M., Wychowanie estetyczne w prywatnych galicyjskich szkołach średnich, [in:] Edukacja. Kultura. Spoleczeństwo. Kultura 2010, ed. B. TECHMAŃSKA and M. ZAWADKA, OpoleWrocław-Lubin 2011.

WROCZYŃSKI R., Dzieje wychowania fizycznego i sportu od końca XVIII wieku do roku 1918, Wrocław 1971. 